\title{
Co-existance of Juvenil Ankylosing Spondylitis with Familial Mediterranean Fever and Takayasu's Arteritis: A Case Report
}

\author{
Juvenil Ankilozan Spondilit, Ailesel Akdeniz Ateşi ve Takayasu Arteriti Birlikteliği: \\ Bir Olgu Sunumu
}

\author{
๑ Betül Sargın, ๑ Gülcan Gürer
}

Adnan Menderes University Faculty of Medicine, Department of Physical Medicine and Rehabilitation, Division of Rheumatology, Aydın, Turkey

Abstract

Juvenile ankylosing spondylitis (JAS) coexisting with Familial Mediterranean Fever (FMF) or Takayusu's arteritis (TA) together with JAS have been reported in the literature. However, co-existance of these three diseases has not been reported yet. Here, we present a 17-year- old female patient presenting with JAS who was subsequently diagnosed with FMF and TA. To the best of our knowledge, this is the first case of JAS presenting with FMF and TA.

Keywords: Juvenil ankylosing spondylitis, Familial Mediterranean Fever, Takayasu's arteritis, pediatric
Öz

Literatürde Ailesel Akdeniz ateşi (AAA) ve JAS, Takayasu arteriti (TA) ve JAS birlikteliği daha önce bildirilmiştir. Bilgilerimize göre şimdiye kadar bu üç hastalığın birlikteliği daha önce bildirilmemiştir. Burada JAS tanılı 17 yaş kadın olguda tesadüfen saptanan AAA ve TA tanısını sunmayı amaçladık. Bu olgu JAS'de AAA ve TA gelişen ilk olgudur.

Anahtar Sözcükler: Juvenil ankilozan spondilit, Ailesel Akdeniz Ateşi, Takayasu arteriti, pediatrik

\section{Case}

A 17-year-old female patient presented with the complaints of fever, abdominal pain and swelling in both feet. She was diagnosed with JAS two years ago with the complaints of inflammatory back pain, magnetic resonance imaging of the sacroiliac joint showing active sacroiliitis and human leukocyte antigen-B27 (HLA-B27) positivity. She described recurrent (periodic) fever, abdominal pain since she was 16 years old. She experienced intermittent attacks of abdominal pain and fever $\left(39-40^{\circ} \mathrm{C}\right)$ for three to five days, then the symptoms resolved spontaneously and completely. She had a normal daily life during the symptomfree period. She was admitted to our rheumatology clinic for these reasons. Written informed consent was obtained from the patient. The general condition was moderate; she was well oriented and cooperative. Physical examination revealed feeble brachial and radial pulses on the right
Address for Correspondence/Yazışma Adresi: Betül Sargın

Adnan Menderes University Faculty of Medicine, Department of Physical Medicine and Rehabilitation, Division of Rheumatology, Aydın, Turkey

Phone: +90 5545929430 E-mail: betul.cakir@yahoo.com ORCID ID: orcid.org/0000-0002-7175-5107 Received/Geliş Tarihi: 1 July 2017 Accepted/Kabul Tarihi: 9 November 2017
Copyright 2018 by The Medical Bulletin of University of Health Sciences Haseki Training and Research Hospital
The Medical Bulletin of Haseki published by Galenos Yayinevi.

Telif Hakkı 2018 Sağlık Bilimleri Üniversitesi Haseki Eğitim ve Araştırma Hastanesi Haseki Tıp Bülteni, Galenos Yayınevi tarafindan basılmışıı. 
and left sides. Also, femoral-popliteal-and dorsalis pedis pulses were normal bilaterally. Heart rate was 98 beatsmin and temperature was $38.5^{\circ} \mathrm{C}$. Her blood pressure was $160 / 80 \mathrm{mmHg}$ on the right upper limb and 110/70 on the left upper limb. The blood pressure on the right and left lower limbs was 160/74 and 163/72 mmHg, respectively. Murmur was absent over the abdominal aorta and epigastric region. No symptoms of vascular insufficiency were observed. Respiratory system examination revealed that both hemithoraces equally contributed to breathing and lung crackles were present in the left lower lobe. Physical examination of the locomotor system revealed tenderness and pain in both feets. Her ophthalmologic examination was normal. The patient's laboratory findings are presented in Table 1 Blood tests revealed anemia with a hemoglobin level of $8.2 \mathrm{~g} / \mathrm{dL}$, hematocrit of $30.4 \%$, white cell count of $9.32 \mu \mathrm{L}$ and platelet count of 517.000 $\mu \mathrm{L}$. Also, laboratory data showed normal serum potassium and creatinine levels as well as glomerular filtration rate. Urine analysis was also normal. FMF mutation analysis showed M694V heterozigot mutation. According to the Tel-Hashomer criteria, the diagnosis of FMF was established (5). She met two major criteria (recurrent fever and serositis) and one minor criterion (positive response to

\begin{tabular}{|l|l|l|}
\hline \multicolumn{3}{|l|}{ Table 1. The laboratory values of the patient } \\
\hline Parameters & Result & Normal range \\
\hline Hemoglobin & $8.2 \mathrm{gr} / \mathrm{dL}$ & $11.7-15.5 \mathrm{gr} / \mathrm{dL}$ \\
\hline Hematocrit & $30.4 \%$ & $37-44$ \\
\hline MCV & $65.0 \mathrm{fL}$ & $80.4-95.9 \mathrm{fL}$ \\
\hline RDW & 22.6 & $11.7-14.6$ \\
\hline Leukocyte count & $9.320 \mathrm{mkrL}$ & $3.800-11.000 \mathrm{mkrL}$ \\
\hline Platelet & $517.000 \mathrm{mkrL}$ & $150.000-350.000 \mathrm{mkrL}$ \\
\hline $\begin{array}{l}\text { Erythrocyte } \\
\text { sedimentation rate }\end{array}$ & $31 \mathrm{~mm} / \mathrm{h}$ & $0-20 \mathrm{~mm} / \mathrm{h}$ \\
\hline C-reactive protein & $10.09 \mathrm{mg} / \mathrm{L}$ & $0-6 \mathrm{mg} / \mathrm{L}$ \\
\hline Urea & $22 \mathrm{gr} / \mathrm{dL}$ & $13-43 \mathrm{gr} / \mathrm{dL}$ \\
\hline Creatinine & $0.6 \mathrm{mg} / \mathrm{dL}$ & $0.7-1.3 \mathrm{mg} / \mathrm{dL}$ \\
\hline ALT & $<6 \mathrm{IU} / \mathrm{L}$ & $0-55 \mathrm{IU} / \mathrm{L}$ \\
\hline Total protein & $7.1 \mathrm{~g} / \mathrm{dL}$ & $6.4-8.3 \mathrm{~g} / \mathrm{dL}$ \\
\hline RF & $1.95 \mathrm{IU} / \mathrm{mL}$ & $0-18 \mathrm{IU} / \mathrm{mL}$ \\
\hline C3 & $118.2 \mathrm{mg} / \mathrm{dL}$ & $85-200 \mathrm{mg} / \mathrm{dL}$ \\
\hline C4 & $38 \mathrm{mg} / \mathrm{dL}$ & $20-50 \mathrm{mg} / \mathrm{dL}$ \\
\hline C-ANCA/ p-ANCA & Negative & Negative \\
\hline HLA-B27 & positive & - \\
\hline FMF mutation analysis & $\begin{array}{l}\text { M694 } \\
\text { heterozigot }\end{array}$ & - \\
\hline $\begin{array}{l}\text { MCV: Mean corpuscular volume, RDW: Red cell distribution width, ALT: Alanin } \\
\text { aminotransferase, RF: Rheumatoid factor, ANCA: Anti-neutrophil cytoplasmic } \\
\text { antibodie, HLA-B27: Human leukocyte antigen-B27, FMF: Familial Mediterranean } \\
\text { Fever }\end{array}$ & \\
\hline
\end{tabular}

colchicine treatment). Her electrocardiogram, transthoracic echocardiogram, magnetic resonance angiography (MRA) of the mesenteric arteries, thoracic, abdominal aorta and duplex ultrasonography were normal. MRA of the upper extremity showed left internal carotid artery stenosis and hypoplasia of the left vertebral artery. Furthermore, there was no flow in the left subclavian artery (Figure 1). To confirm the diagnosis of vasculitis a biopsy was taken from the left subclavian artery. Hypertrophy and mononuclear cell infiltration was seen in all the three layers in histological examination. Finally, angioplasty was performed. After surgery, her blood pressure was $110 / 70 \mathrm{mmHg}$ on both the right and left upper limbs, 100/70 on both the right and left lower limbs. The patient was diagnosed as having FMF and TA simultaneously. Colchicine $(1.5 \mathrm{mg})$, prednisolone (1 $\mathrm{mg} / \mathrm{kg}$ body weight) and amlodipine $(10 \mathrm{mg}$ ) were administered first. The patient had used acetylsalicylic acid (100 mg) and dipyridamole (150 mg) before and acetylsalicylic acid (100 mg) and clopidogrel (75 mg) after biopsy. Then, methotrexate $(20 \mathrm{mg}$ ) and folic acid ( 5 $\mathrm{mg}$ ) were started. Due to side effects, methotrexate was switched to azathioprine $(150 \mathrm{mg})$ treatment. Her fever and abdominal pain regressed with colchicine treatment. She is currently under clinical follow-up.

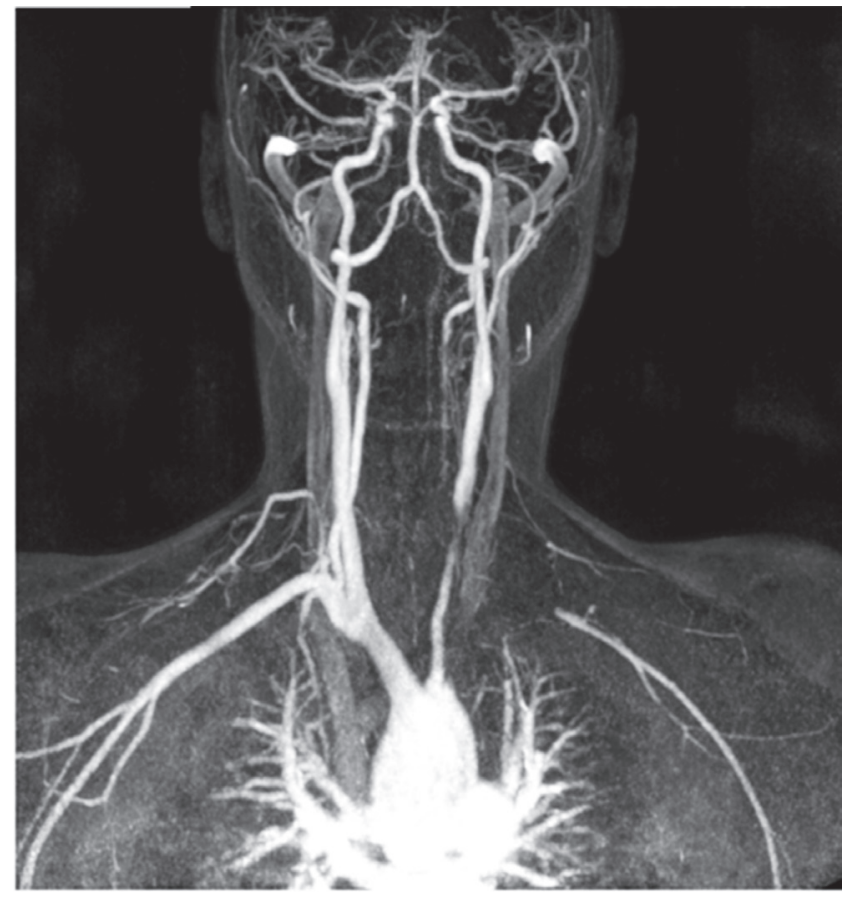

Figure 1. Upper extremity magnetic resonance angiography

\section{Discussion}

To our knowledge, this is the first reported case of JAS presenting with FMF and TA. In the literature, there have 
been studies investigating the co-existeance of FMF and AS and prevalence of AS or spondyloarthritis (SpA) among FMF patients. Dilsen (6) reported the first case of FMF in a patient with AS in 1963. After this report, Kasifoglu et al. (7) reported that the frequency of sacroiliitis was 7\% among 256 FMF patients. Akar et al. (8) reported fifteen FMF patients (7.5\%) and nine unaffected firstdegree relatives fulfilled the modified New York criteria for AS among 157 FMF patients (78.1\%) and 233 (73\%) unaffected first-degree relatives. Akkoc and Gul (9) reported increased prevalence of AS or SpA among FMF patients. How FMF develops in patients with AS is poorly understood. Kasifoglu et al. (7) suggested that HLA-B27 positivity and/or M694V mutation may play a role in the development of sacroiliitis and the severity of seronegative SpA. Also, Akar et al. (8) indicated that factors other than HLA-B27 play a role in the association of FMF and SpA/ AS. MEFV gene variations may be one of the geographic/ region-specific potential pathogenetic links between these two disorders in the Turkish population. Akkoc and Gul (9) stated that MEFV gene mutations regulates interleukin$1 \beta$ (IL) activation. A genome-wide association study by Reveille et al. (10) included 2.053 unrelated AS cases among people of European descent and 5.140 ethnically matched controls, with replication in an independent cohort of 898 AS cases and 1.518 controls. It has been reported that four genetic loci associated with the risk of AS and identified a major role for the IL-23 and IL-1 cytokine pathways in AS. Therefore, association of FMF with AS can be explained. In their study in 2012, Zihni et al. (11) reported a case of co-existeance of FMF with TA.

FMF-associated vasculitis mechanisms involve environmental factors on the context of genetic predisposition. FMF-associated vasculitis cases had MEFV gene mutations. These mutations may be considered in the pathogenesis.

FMF is a prototype of autoinflammatory diseases. It is caused by inherited loss-of- function mutations in Pyrin which plays an important role in control and regulation of inflammation with an enzyme, Caspase-1, and it's target cytokine, IL-1 $\beta$ (12). Once activated, Caspase-1 proteolytically cleaves prolL-1 $\beta$ into an active IL-1 $\beta$ with a proinflammatory effect (13). Therefore, the mechanism of the overproduction of IL-1 in FMF can be explained.

Co-existeance of AS with TA is infrequent, and their association is even rarer. In a study conducted by Gan et al. (14), 6 patients fulfilled diagnostic criteria for AS and TA. The Authors indicated that there was no association between HLA-B27 and the pathogenesis of AS with TA.
Our patient is the first reported case of JAS presenting with FMF and TA. We suggest that FMF and TA can be seen in JAS patients. TA patients should be carefully followed until a final diagnosis can be clearly made.

\section{Ethics}

Informed Consent: A consent form was completed by all participants.

Peer-review: Externally peer-reviewed.

\section{Authorship Contributions}

Surgical and Medical Practices: G.G., B.S. Concept: B.S. Design: G.G., B.S. Data Collection or Processing: G.G., B.S. Analysis or Interpretation: G.G., B.S. Literature Search: G.G., B.S. Writing: B.S

Conflict of Interest: No conflict of interest was declared by the authors.

Financial Disclosure: The authors declared that this study received no financial support.

\section{References}

1. Sandhya P, Danda D, Jeyaseelan L. Are Indian patients with juvenile-onset ankylosing spondylitis taller than reference population ? Indian J Med Res 2015;141:446-53.

2. Rudwaleit $M$, Van der Heijde $D$, Landewé $R$, et al. The development of Assessment of SpondyloArthritis international Society classification criteria for axial spondyloarthritis (part II): validation and final selection. Ann Rheum Dis 2009;68:77783.

3. Tunca M, Akar S, Onen F, et al. Familial Mediterranean fever (FMF) in Turkey: results of a nationwide multicenter study. Medicine (Baltimore) 2005;84:1-11.

4. Castaner E, Alguersuari A, Andreu M, Gallardo X, Spinu C, Mata JM. Imaging findings in pulmonary vasculitis. Semin Ultrasound CT MR 2012;33:567-79.

5. Mor A, Shinar Y, Zaks N, et al. Evaluation of disease severity in familial Mediterranean fever. Semin Arthritis Rheum 2005;35:57-64.

6. Dilsen N. Familial Mediterranean fever (periodic disease) associated with ankylopoietic spondylitis (Apropos of a case). Turk Tip Cemiy Mecm 1963;29:160-7.

7. Kasifoglu T, Calisir C, Cansu DU, Korkmaz C. The frequency of sacroiliitis in familial Mediterranean fever and the role of HLA-B27 and MEFV mutations in the development of sacroiliitis. Clin Rheumatol 2009;28:41-6.

8. Akar S, Soysal O, Balci A, et al. High prevalence of spondyloarthritis and ankylosing spondylitis among familial Mediterranen fever patients and their first-degree relatives: further evidence for the connection. Arthritis Res Ther 2013;15:21.

9. Akkoc N, Gul A. Familial Mediterranean fever and seronegative arthritis. Curr Rheumatol Rep 2011;13:388-94. 
10. Reveille JD, Sims AM, Danoy $P$, et al. Genome - wide association study of ankylosing spondylitis identifies nonMHC susceptibility loci. Nat Genet 2010;42:123-7.

11. Zihni FY, Kalfa M, Ocakçı PT, et al. Coexistence of Takayasu's arteritis with familial Mediterranean fever. Rheumatol Int 2012;32:1675-8.

12. Bozkurt Y, Demir A, Erman B, Gül A. Unified Modeling of Familial Mediterranean Fever and Cryopyrin Associated
Periodic Syndromes. Comput Math Methods Med 2015;2015:893507.

13. Doherty TA, Brydges SD, Hoffman HM, "Autoinflammation :translating mechanism to therapy," Journal of Leukocyte Biology, vol. 90, no. 1, pp. 37-47, 2011.

14. Gan FY, Fei YY, Li MT, et al. The characteristics of patients having ankylosing spondylitis associated with Takayasu's arteritis. Clin Rheumatol 2014;33:355-8. 